\title{
Level of Awareness on Climate Change of Farm Women of West Garo Hills, Meghalaya
}

\author{
Puspita Das* and Nikrachi Ch. Sangma
}

\author{
Department of Extension Education and Communication Management, College of Community \\ Science, Central Agricultural University, Tura, Meghalaya, India
}

*Corresponding author

\section{A B S T R A C T}

\begin{tabular}{|l|}
\hline Ke y w o r d s \\
Awareness, \\
$\begin{array}{l}\text { Indicators, Causes, } \\
\text { Adaptation } \\
\text { strategies, Climate } \\
\text { change }\end{array}$ \\
\hline Article Info \\
\hline $\begin{array}{l}\text { Accepted: } \\
\text { 10 September } 2020 \\
\text { Available Online: } \\
\text { 10 October } 2020\end{array}$ \\
\hline
\end{tabular}

Present study was undertaken to identify extent of awareness of farm women regarding climate change. A total of hundred samples were collected for the present study. The results revealed that during pre-intervention respondents had attained low level of awareness regarding indicators on climate change whereas after post-intervention there level of awareness regarding indicators on climate change were in high level. According to their level of causes of climate change, during pre-intervention 100 per cent of the respondents had attained low level of awareness regarding causes of climate change whereas after post-intervention 98 per cent of the respondents had attained high level on causes of climate change. Similarly, during pre-intervention respondents were attained low level of awareness regarding adaptation practices to climate change whereas after postintervention respondents were attained high level of awareness regarding adaptation practices to climate change. The post-intervention results shows that majority of the respondents were gained in knowledge on adaptation strategies to cope up with climate change. The finding shows that training programmes were organized on different aspects of climate change as intervention programme. The study was undertaken under All India Coordinated Research Project on Home Science under the sub project "Empowerment of Farm Women on Climate Change".

\section{Introduction}

Climate change describes a change in the average conditions such as temperature and rainfall in a region over a long period of time. It is the defining issue of time at a defining moment. From shifting weather patterns that threaten food production, to rising sea levels that increase the risk of catastrophic flooding, the impact of climate change are global in scope and unprecedented in scale. It has dramatic impacts on natural resources, economic activities, food security, health and physical infrastructure. India is one of the countries most strongly affected by climate change and the threat is especially great whatever people's livelihoods are particularly dependent on natural resources. In these vulnerable areas, climate adaptation measures are of central importance or the protection of rural livelihoods and for ensuring sustainable development. The Intergovernmental Panel on 
Climate Change (IPCC, 2001) defines climate change as any change in climate over time whether due to natural variability or as a result of human activity. Similarly, Manstradrea and Schneider (2009) enumerate climate change as a long term alteration in global weather patterns such as increases in temperature and storm activity, often linked to the potential consequence of rising levels of heat trapping gases known as green house gas which retain the radiant energy provided to the earth by the sun in a process known as the green house effect.

North-eastern region is expected to be highly prone to consequences of climate change due to it's geographically fragility. Climate change process which is reflected in erratic weather, abrupt rising temperature, deficiency in rainfall, humidity variation and increase unpredictability of weather. The number of hot days and hot nights show an increasing trend while that of cold days and cold night shows declining trend in Meghalaya. The changing climate in Meghalaya would have widespread implication for agriculture, water resources, forest, biodiversity human and animal health. In the state of Meghalaya where agriculture is a predominantly rain fed and variation and unpredictability leading to farmers insecurity.

Climate sensitivity of the state comes from the fragile ecosystem of the region where it is located extending to about 22,429 sq.kms. the varied physiological features of the state and the altitudinal differences gives rise to varied types of climate ranging from near tropical to temperature and alpine which is likely to distributed considerably under the impact of weather variability.

The vulnerability of the state to water induced disasters because of its location in the eastern Himalayan periphery, fragile geoenvironmental setting and economic under development is likely to poses considerable threat to the resilience of poorer and vulnerable community.

Climate change has a long lasting impact on natural resources, economic activities, food security, health, physical infrastructure and society in general. More than half of the population of India of more than 1 billion people lives in rural areas and their livelihood depend on climate sensitive sectors such as agriculture, fishery and forestry. Those who stay in urban or semi-urban also dependants on the rural livelihood as most of the production of food crops are from local areas. Hence climate change adaptation measures are of national importance in order to ensure the protection of rural livelihoods, to preserve the country's natural resources, and to foster sustainable development.

Considering all the point a research study was undertaken with following objectives include to study the background profile of the respondents. To explore their level of awareness on indicators of climate change. To identify the causes of climate change faced by the farm women and also to know their adaptation practices of climate change.

\section{Materials and Methods}

The study was carried out under AICRP Home Science Project. The study was undertaken in the three villages of West Garo Hills, Meghalaya. The selected villages were Aminda Rangsagre, Aminda Simsangand Aminda Kongkrang of Gambegre Block was selected randomly.

The data was collected from 100 farm women of selected villages randomly. The interview scheduled was prepared to identify their extent awareness of farm women regarding climate change. 


\section{Results and Discussion}

\section{Profile of the respondents}

\section{Age}

Fig. 1 indicates that large percentage $(53 \%)$ of the respondents belonged to young age (18$35 y$ rs.) and the least percentage $(15 \%)$ of the respondents belonged to upper middle age (51 years and above). The finding shows that majority of the respondents were from young age group.

\section{Educational Qualification}

It was found from fig. 2 that large percentage (26\%) of the respondents can read and write followed by 25 percent were studied up to middle schools, 23 percent of the respondents have studied up to primary schools whereas 2 per cent of the respondents have education up to graduation and only 1 per cent of the respondents had post graduated. The finding shows that respondents can read and write by their own.

\section{Marital status}

It is revealed from the fig. 3 that large percentages $(72 \%)$ of the respondents were married followed by 28 per cent of the respondents belonged to unmarried. This finding shows that majority of the respondents were married because in that respective area they get married at early age.

\section{Occupation of respondents}

Fig. 4 revealed that majority of the respondents $(85 \%)$ were housewife followed by 13 per cent of the respondents were engaged in government service and only 2 per cent of the respondents were open up the small enterprises. The finding shows that most of the respondents were housewife so that they can take care of their children's and family in a proper way.

\section{Family occupation}

It is revealed from the fig. 5. That 52 per cent of the respondents' family was engaged in daily wage earner followed by farming (39\%), business $(7 \%)$ and government service $(2 \%)$. The finding shows that their family's occupation of the respondents were predominantly from daily wage earner.

Table 1 indicates that during pre-intervention majority of the respondents were not aware about indicators of climate change namely; Increase in melting of glacier, Change in intensity and frequency of storm, Decline of soil productivity, occurrence of extreme event (i.e. cold wave, heat wave \& heavy fog), and frequent flood. Similarly after postintervention they were aware about various indicators of climate change namely; increased in temperature, changes in water level, change in length of season, irregular and erratic rainfall. The finding shows that after attending the training programme on climate change majority of the respondents were somewhat aware on indicators of climate change so the training programme provided awareness on different indicators of climate change.

From table 2, it is clearly reveals that during pre-intervention respondents had attained low level of awareness regarding indicators on climate change whereas after postintervention there level of awareness regarding indicators on climate change were in high level. It shows that respondents got benefitted from the training programme. 


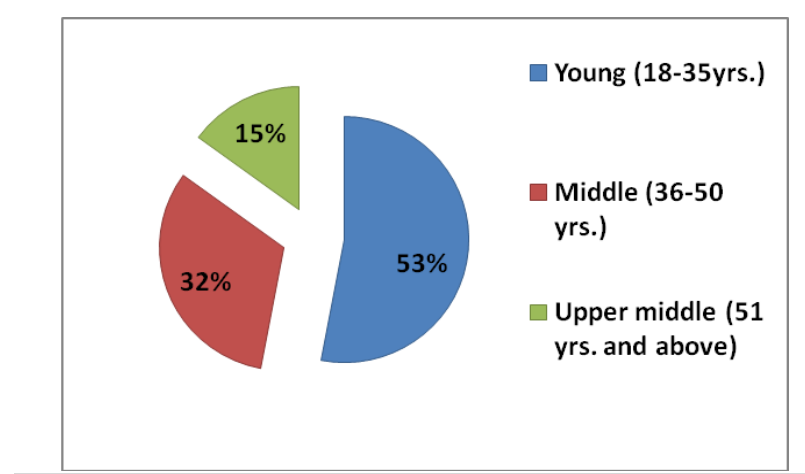

Fig 1: Distribution of respondents according to their age

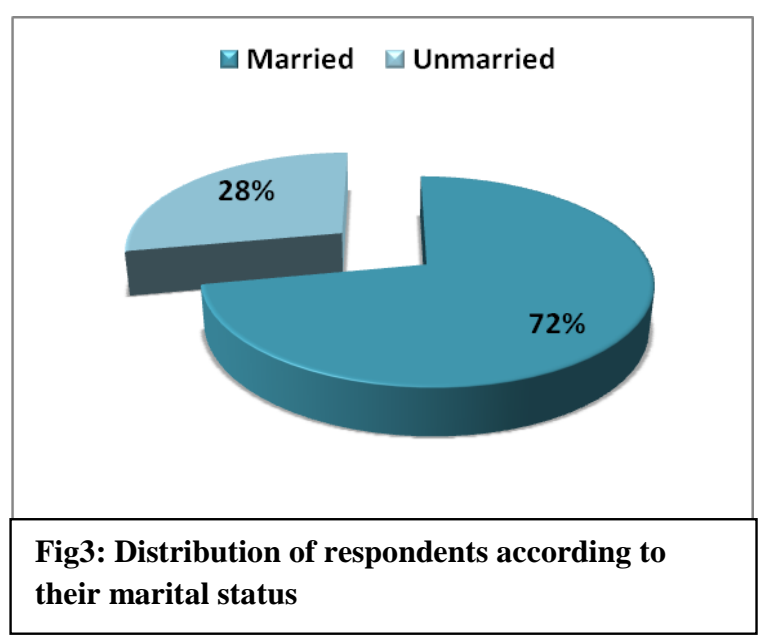

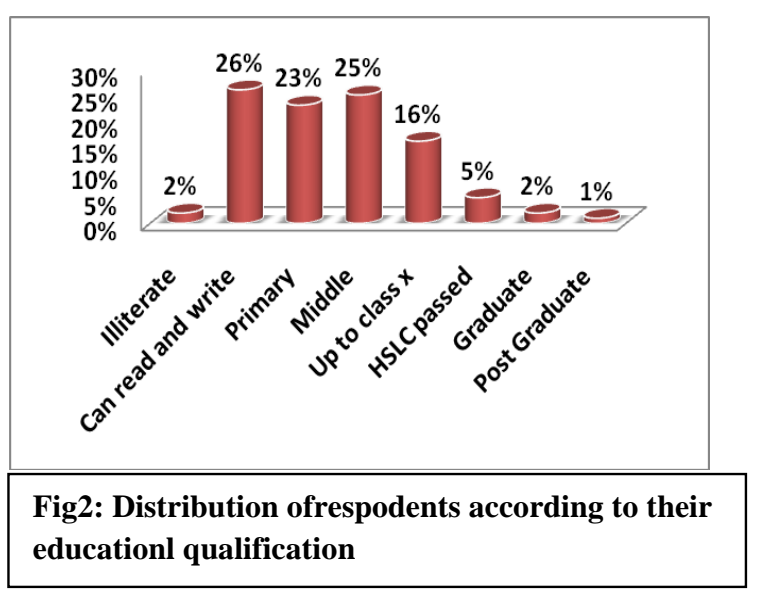

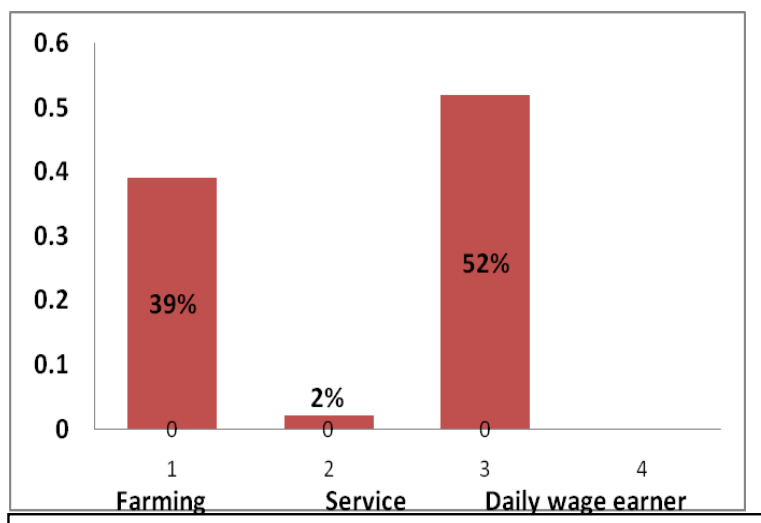

Fig: Distribution of respondents according to their occupation of respondents

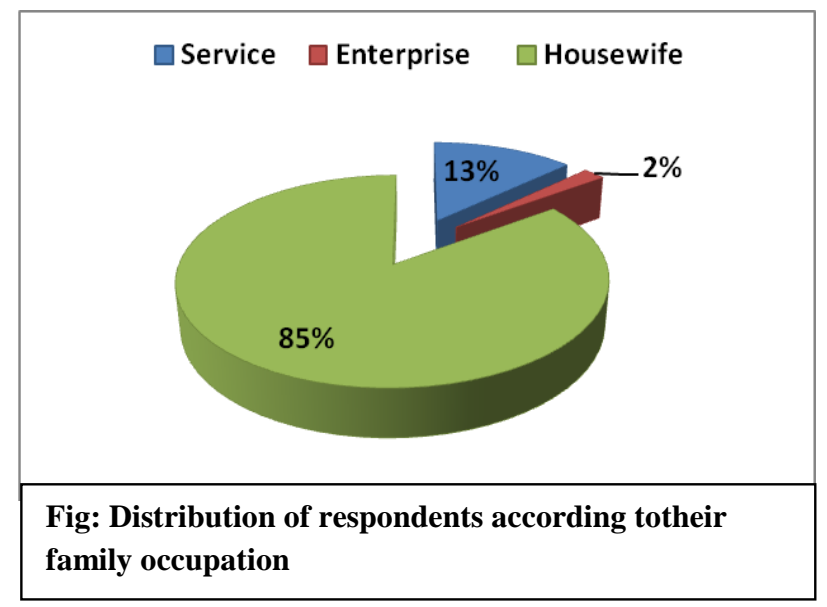


Table.1 Distribution of respondents according to the level of awareness on indicators on climate change $(n=100)$

\begin{tabular}{|c|c|c|c|c|c|c|}
\hline \multirow[t]{3}{*}{ Indicators /Phenomenon } & \multicolumn{6}{|c|}{$\begin{array}{l}\text { Mean score } \\
\text { (Range 0-2) }\end{array}$} \\
\hline & \multicolumn{2}{|c|}{ Fully aware } & \multicolumn{2}{|c|}{ Somewhat } & \multicolumn{2}{|c|}{ Not aware } \\
\hline & Pre & Post & Pre & Post & Pre & Post \\
\hline Increase in melting of glacier & - & - & - & 17 & 100 & 83 \\
\hline Increase in temperature & - & 11 & 23 & 56 & 77 & 33 \\
\hline Changes in water level & - & 09 & 19 & 49 & 81 & 42 \\
\hline Irregular and erratic rainfall & - & 14 & 13 & 47 & 87 & 39 \\
\hline $\begin{array}{l}\text { Change in length of season } \\
\text { Short winter } \\
\text { Long summer }\end{array}$ & $\begin{array}{l}- \\
-\end{array}$ & $\begin{array}{l}17 \\
17\end{array}$ & $\begin{array}{l}15 \\
11\end{array}$ & $\begin{array}{l}59 \\
59\end{array}$ & $\begin{array}{l}85 \\
89\end{array}$ & $\begin{array}{l}24 \\
24\end{array}$ \\
\hline $\begin{array}{l}\text { Change in intensity and } \\
\text { frequency of storm }\end{array}$ & - & 12 & - & 41 & 100 & 47 \\
\hline Decline of soil productivity & - & 15 & - & 57 & 100 & 28 \\
\hline $\begin{array}{c}\text { Occurrence of extreme event } \\
\text { Cold wave } \\
\text { Heat wave } \\
\text { Heavy fog }\end{array}$ & $\begin{array}{l}- \\
- \\
-\end{array}$ & $\begin{array}{l}- \\
- \\
-\end{array}$ & $\begin{array}{l}- \\
- \\
-\end{array}$ & $\begin{array}{l}17 \\
11 \\
19\end{array}$ & $\begin{array}{l}100 \\
100 \\
100\end{array}$ & $\begin{array}{l}83 \\
89 \\
81\end{array}$ \\
\hline Frequent flood & - & 21 & - & 42 & 100 & 47 \\
\hline
\end{tabular}

Table.2 Level of awareness regarding indicators on climate change

\begin{tabular}{|c|c|c|c|c|c|c|}
\hline \multirow[t]{2}{*}{ Intervention } & \multicolumn{2}{|c|}{$\begin{array}{l}\text { Pre-intervention } \\
\text { Percentage of } \\
\text { respondents }\end{array}$} & \multicolumn{2}{|c|}{$\begin{array}{l}\text { Post intervention } \\
\text { Percentage of } \\
\text { respondents }\end{array}$} & \multicolumn{2}{|c|}{$\begin{array}{l}\text { Mean score } \\
\text { ( Range 0-2) }\end{array}$} \\
\hline & f & $\%$ & f & $\%$ & $\begin{array}{l}\text { Pre } \\
\text { intervention }\end{array}$ & $\begin{array}{l}\text { Post } \\
\text { intervention }\end{array}$ \\
\hline $\begin{array}{c}\text { Low } \\
(0-0.66)\end{array}$ & 55 & 55 & - & - & \multirow{3}{*}{0.53} & \multirow{3}{*}{1.50} \\
\hline $\begin{array}{c}\text { Medium } \\
(\mathbf{0 . 6 7 - 1 . 3 3})\end{array}$ & 45 & 45 & 20 & 20 & & \\
\hline $\begin{array}{c}\text { High } \\
(\mathbf{1 . 3 4 - 2 . 0})\end{array}$ & - & - & 67 & 80 & & \\
\hline
\end{tabular}


Table.3 Distribution of respondents according to the level of awareness of causes of climate change

\begin{tabular}{|c|c|c|c|c|c|c|}
\hline \multirow[t]{3}{*}{ Statement } & \multicolumn{6}{|c|}{ Level of awareness } \\
\hline & \multicolumn{2}{|c|}{ Fully aware $(\%)$} & \multicolumn{2}{|c|}{ Somewhat (\%) } & \multicolumn{2}{|c|}{ Not aware $(\%)$} \\
\hline & Pre & Post & Pre & Post & Pre & Post \\
\hline Deforestation & - & 29 & 61 & 71 & 39 & - \\
\hline Increase in number of vehicles & - & 43 & 48 & 57 & 52 & - \\
\hline Overpopulation & - & 79 & 32 & 21 & 68 & - \\
\hline Industries and factories & - & 81 & - & 19 & 100 & - \\
\hline Use of pesticides & - & 88 & - & 12 & 100 & - \\
\hline Burning of fossils and farm waste & - & 72 & - & 28 & 100 & - \\
\hline Use of electrical appliances & - & 77 & - & 23 & 100 & - \\
\hline Pollution & - & 81 & 33 & 19 & 67 & - \\
\hline Global warming & - & 85 & 29 & 15 & 71 & - \\
\hline Natural disaster & - & 93 & - & 7 & 100 & - \\
\hline Rapid urbanization & - & 47 & - & 53 & 100 & - \\
\hline Any other & - & 33 & - & 67 & 100 & - \\
\hline
\end{tabular}

Table.4 Distribution of respondents according to the level of awareness regarding causes of climate change

$n=100$

\begin{tabular}{|c|c|c|c|c|c|}
\hline \multirow{2}{*}{$\begin{array}{c}\text { Level of } \\
\text { Awareness }\end{array}$} & \multicolumn{2}{|c|}{ Percentage $(\%)$} & \multicolumn{2}{|c|}{ Mean } & \multirow[t]{2}{*}{ SD } \\
\hline & Pre & Post & Pre & Post & \\
\hline Low & 100 & - & \multirow{3}{*}{0} & \multirow{3}{*}{1.67} & \multirow{3}{*}{0.15} \\
\hline Medium & - & 2 & & & \\
\hline High & - & 98 & & & \\
\hline
\end{tabular}


Table.5 Distribution of respondents according to awareness regarding adaptation practices for climate change

\begin{tabular}{|c|c|c|c|c|c|c|}
\hline \multirow[t]{3}{*}{ Statement } & \multicolumn{6}{|c|}{ Level of awareness } \\
\hline & \multicolumn{2}{|c|}{ Fully aware (\%) } & \multicolumn{2}{|c|}{ Somewhat (\%) } & \multicolumn{2}{|c|}{ Not aware $(\%)$} \\
\hline & Pre & Post & Pre & Post & Pre & Post \\
\hline Diversification of crop type & - & 29 & - & 71 & 100 & - \\
\hline Diversification of crop varieties & - & 29 & - & 71 & 100 & - \\
\hline Change in planting calendar & - & 32 & - & 62 & 100 & - \\
\hline Change in use of chemical fertilizers & - & 21 & - & 79 & 100 & - \\
\hline Change in use of chemical pesticides & - & 21 & - & 79 & 100 & - \\
\hline $\begin{array}{l}\text { Implementing soil conservation } \\
\text { methods }\end{array}$ & - & 77 & - & 23 & 100 & - \\
\hline $\begin{array}{l}\text { Adopting water harvesting } \\
\text { techniques }\end{array}$ & - & 19 & - & 81 & 100 & - \\
\hline Change in agronomic practices. & - & 64 & - & 36 & 100 & - \\
\hline Mulching of soil & - & 83 & - & 17 & 100 & - \\
\hline $\begin{array}{l}\text { Changing the traditional irrigation } \\
\text { method }\end{array}$ & - & 86 & - & 14 & 100 & - \\
\hline $\begin{array}{l}\text { Switching from mono cropping to } \\
\text { integrated farming systems }\end{array}$ & - & 79 & - & 21 & 100 & - \\
\hline Adoption of crop rotation & - & 33 & - & 67 & 100 & - \\
\hline
\end{tabular}

Table.6 Distribution of respondents according to the level of awareness regarding adaptation strategies to cope up with climate change

\begin{tabular}{|c|c|c|c|c|c|}
\hline $\begin{array}{c}\text { Level of } \\
\text { Awareness }\end{array}$ & \multicolumn{2}{|c|}{ Percentage (\%) } & \multicolumn{2}{|c|}{ Mean } & \multirow{2}{*}{ SD } \\
\hline Low & Pre & Post & Pre & Post & \\
\hline Medium & 100 & - & & & \multirow{2}{*}{0.20} \\
\hline High & - & 31 & 0 & 1.48 & \\
\hline
\end{tabular}


Table.7 Distribution of respondents according to the level of awareness regarding climate change (Overall)

\begin{tabular}{|c|c|c|c|c|c|}
\hline \multirow[t]{2}{*}{ Level of Awareness } & \multicolumn{2}{|c|}{ Percentage (\%) } & \multicolumn{2}{|c|}{ Mean } & \multirow[t]{2}{*}{ SD } \\
\hline & Pre & Post & Pre & Post & \\
\hline Low & 100 & - & \multirow{3}{*}{0} & \multirow{3}{*}{1.55} & \multirow{3}{*}{0.094} \\
\hline Medium & - & - & & & \\
\hline High & - & 100 & & & \\
\hline
\end{tabular}

From table 3 , it indicates that during preintervention 100 percent of the respondents were not aware about level of awareness of causes of climate change namely; industries and factories, use of pesticides, burning of fossils and farm waste, use of electrical appliances, natural disaster, rapid urbanization whereas after post-evaluation 93 percent of the respondents were aware about natural disaster followed by 88 percent on use of pesticides, 85 percent in global warming, 81 percent each in industries and factories and pollution and so on. The finding shows that after providing training programme to them respondents were aware on causes of climate change.

From table 4, It is clearly reveals that during pre-intervention 100 percent of the respondents had attained low level of awareness regarding causes of climate change whereas after post-intervention 98 percent $\mathrm{o}$ the respondents had attained high level on causes of climate change. It shows that respondents were benefitted from the training programme.

Table 5 revealed that entire respondents were not aware about adaptation practices for climate change whereas after postintervention 86 percent of the respondents were aware about adaptation practices in changing the traditional irrigation method followed by 83 percent of the respondents in mulching of soil, 79 percent of the respondents in switching from mono cropping to integrated farming system and so on. The finding shows that the respondents were aware about adaptation practices for climate change in various aspects like mulching of soil, switching of mono cropping to IFS and so on.

From table 6, it indicates that during preintervention respondents were attained low level of awareness regarding adaptation strategies to cope up with climate change whereas after post-intervention respondents were attained high level of awareness regarding adaptation strategies to cope up with climate change. The post-intervention results shows that majority of the respondents were gained in knowledge on adaptation strategies to cope up with climate change.

Table 7 revealed that during pre-intervention majority of the respondents were attained a low level of awareness regarding climate change whereas after post-intervention respondents were attained a high level of awareness regarding climate change overall. The finding shows that after providing a training programme to them their knowledge were gained and its benefited to them.

It can be concluded from the present study that awareness training are important factor enhancing capacities of Farm women. The 
present study shows that the respondents during pre-intervention were not aware about various aspects of climate change namely; indicators, causes and adaptation practices to cope up with climate change. After studying pre-intervention results training programme were organised and all the respondents were attended the training programme on climate change. So far after two to three months of training programme post intervention data was collected and analyse it where the results show a positive and encouraging result. It reflects from the findings that their level of awareness regarding indicators of climate change, causes of climate change and adaptation strategies to cope up with climate change were attained a high level. Hence it can be concluded that organization of awareness and training programmes are the need of the hour.

\section{References}

Chaturvedi A. (2019). Climate change Adaptation - North Eastern Region. Deutsche Gesellchaft fur International
Zusammenarbeit (GIZ) GmbH. Ministry of Development of North Eastern Region

Climate change. United Nations Peace, dignity and equality on a healthy planet. www.un.org.

https://climatekids.nasa.gov

Government of Meghalaya. (). Meghalaya State Climate Change Action Plan. Deutsche Gesellchaft fur International Zusammenarbeit (GIZ) $\mathrm{GmbH}$

IPCC TAR WGI (2001). Thereport Climate change 2007: The Physical Science Basis. In S Solomon, D. Qin, $\mathrm{M}$. Manning, Z. Chen, M. Marquis, K. B. Averyt, M. Tignor, H. I. Miller (eds). Contribution of working Group I to the Third Assessment Report of the International Panel on Climate Change. Cabridge University Press, Cambridge, UK and New York, USA.

Manstrandrea, M. D. and Schneider, S. H. (2009). Global Warming. Microsoft Encarta Online Encyclopedia.

\section{How to cite this article:}

Puspita Das and Nikrachi Ch. Sangma. 2020. Level of Awareness on Climate Change of Farm Women of West Garo Hills, Meghalaya. Int.J.Curr.Microbiol.App.Sci. 9(10): 1045-1053. doi: https://doi.org/10.20546/ijcmas.2020.910.125 